\title{
Therapeutically effective covalent spike protein inhibitors in treatment of SARS-CoV-2
}

\author{
Vikram Choudhary ${ }^{1} \cdot$ Amisha Gupta $^{1} \cdot$ Rajesh Sharma $^{1} \cdot$ Hamendra Singh Parmar $^{2}$
}

Received: 20 February 2021 / Revised: 13 August 2021 / Accepted: 16 August 2021 / Published online: 15 September 2021

(c) The Author(s), under exclusive licence to Springer Nature Singapore Pte Ltd. 2021

\begin{abstract}
COVID-19 [coronavirus disease 2019] has resulted in over 204,644,849 confirmed cases and over 4,323,139 deaths throughout the world as of 12 August 2021, a total of 4,428,168,759 vaccine doses have been administered. The lack of potentially effective drugs against the virus is making the situation worse and dangerous. Numerous forces are working on finding an effective treatment against the virus but it is believed that a de novo drug would take several months even if huge financial support is provided. The only solution left with is drug repurposing that would not only provide effective therapy with the already used clinical drugs, but also save time and cost of the de novo drug discovery. The initiation of the COVID-19 infection starts with the attachment of spike glycoprotein of SARS-CoV-2 to the host receptor. Hence, the inhibition of the binding of the virus to the host membrane and the entry of the viral particle into the host cell are one of the main therapeutic targets. This paper not only summarizes the structure and the mechanism of spike protein, but the main focus is on the potential covalent spike protein inhibitors.
\end{abstract}

Keywords Spike protein $\cdot$ COVID-19 $\cdot$ SARS-CoV-2 Drug repurposing $\cdot$ Arbidol $\cdot$ Transmembrane protease serine-type 2

\section{Introduction}

Coronavirus disease 2019 [COVID-19], an infection caused by SARS-CoV-2 has proven to infect over $204,644,849$ confirmed cases and over 4,323,139 deaths throughout the world as of 12 August 2021, a total of 4,428,168,759 vaccine doses have been administered (Coronavirus research centre 2021). Fertility compromise and irreversible lung damage are some of the long-term consequences of COVID-19 patients that suffer from severe infection (Hosseiny et al. 2019; Chen and Lou 2020). COVID-19 pandemic is not only responsible for the health crisis, but also for the on-going economic crisis throughout the world. The increasing damaging effect of COVID-19 has involved the whole world in working intensively in finding an effective therapeutic agent

Rajesh Sharma

rajeshsopdavv@gmail.com

1 School of Pharmacy, Devi Ahilya Vishwavidyalaya, Takshila Campus, Khandwa Road (Ring Road), Indore 452001,

Madhya Pradesh, India

2 School of Biotechnology, Devi Ahilya Vishwavidyalaya, Takshila Campus, Khandwa Road, Indore 452001, Madhya Pradesh, India and preventive measures to fight the SARS-CoV-2 infection (Cascella et al. 2020). Statistics of Milken Institute reports over 300 treatment options and over 200 vaccine candidates are under the developmental phase worldwide as of December 2020. Vaccine development and de Novo drug development cannot be accomplished within months or years, even huge monetary support is provided (Kaitin 2010a). Because of this concern, a more promising alternative could be the search for already known drugs for the therapy of COVID19 to save the world from this pandemic (Fehr and Perlman 2015).

Drug repurposing, also known as drug redirecting, repositioning, re-profiling, or rediscovering can be used for the development of innovative uses of a drug in addition to its original therapeutic use (Baker et al. 2018). Drug repurposing can result in a successful lowering of the money and time cost required in drug development (Baker et al. 2018). The outbreak of COVID-19 has resulted in the repurposing of several clinical drugs for its treatment, such as chloroquine, lopinavir, ritonavir, arbidol, ribavirin, etc. (Maxmen 2020). The therapeutic agents against SARSCoV-2 can be classified into two extensive categories. The first category is agent that acts on the human immune system and the second category acts on the SARS-CoV-2 
virus itself. The latter can be further categorized into two: first being the inhibitors of viral RNA replication and synthesis, and second, those inhibit the binding of the virus with the human cell receptor as evident from the structure of coronavirus shown in Fig. 1 (Wu et al. 2020a).

The viral entry into the cell is facilitated by the spike [S] protein of the SARS-CoV-2 virus. The viral entry results by binding of the spike protein to the receptors on the host cell and leading to the cell membrane fusion (Hoffmann et al. 2020a). Additionally, before the spike protein shows its action, it needs to be cleaved and activated by the host cell's cellular proteases (Hoffmann et al. 2020a). According to a recent study, two cellular proteases can result in the priming of the $\mathrm{S}$ protein of coronavirus that are transmembrane protease serine-type 2 [TMPRSS2] and endosomal cysteine proteases cathepsin $\mathrm{B} / \mathrm{L}[\mathrm{CatB} / \mathrm{L}]$. Meanwhile, the cleavage of carboxypeptidase angiotensin-converting enzyme 2 [ACE2], the host receptor of the spike protein, is a consequence of TMPRSS 2 that finally results in the augmentation of the infection (Heurich et al. 2014). Thus, the complete inhibition of the viral entry of the SARS-CoV-2 necessitates the concurrent blockage of CatB/L and TMPRSS2 (Hoffmann et al. 2020a).

The drug discovery was mainly focused on non-covalent drugs historically. It is believed that irreversible covalent drugs exhibit toxicity and off-target effects (Singh et al. 2011). However, recently, people have realized that covalent drugs have some additional advantages in comparison to non-covalent drugs, such as [i] enhanced biochemical efficiency as they have a more competitive nature than non-covalent endogenous co-factors and substrates (Mah et al. 2014); [ii] reduced and less frequent dosing resulting in reduced patient burden and drug resistance (Mah et al. 2014); [iii] target specificity can be improved by cautiously designing structure targeting particular residues (Cuesta et al. 2020; Fell et al. 2020).

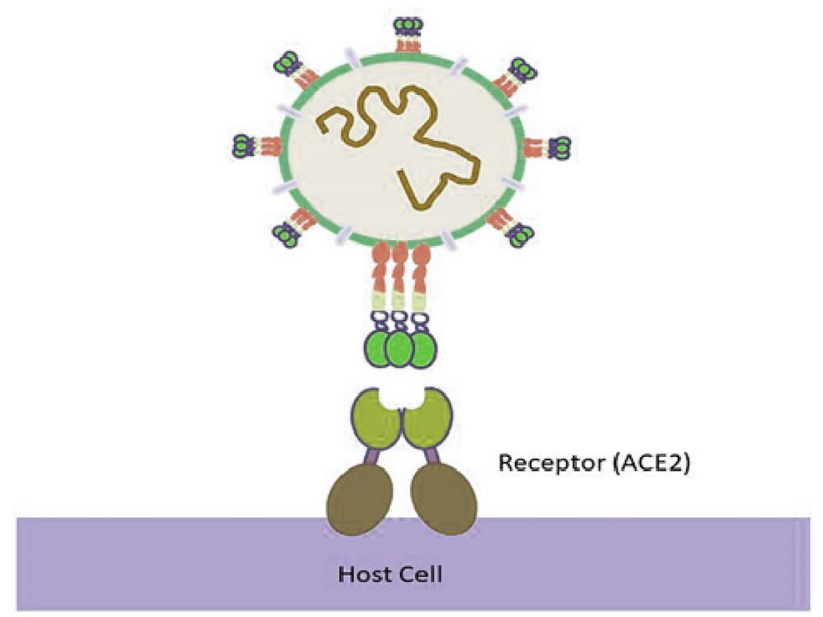

Fig. 2 Binding of S spike protein to the ACE2 receptor

In this review article, we have summarized the structure of the SARS-CoV-2 and the mechanism of infection as well as the treatment options that work as covalent spike protein inhibitors. This paper describes some potential covalent spike protein inhibitors.

\section{Structure and mechanism of spike [S] protein}

The binding of the SARS-CoV-2 to the host cell membrane is mediated through spike [S] protein that is a transmembrane structural class I fusion protein. It exists in a perfusion metastable conformation (Walls et al. 2016; Kirchdoerfer et al. 2016, 2020). Lying on the outer membrane of the SARS-CoV-2 virus, the spike glycoprotein is a 1273-amino-acid-long structural polypeptide comprising two subunits that interact with the angiotensin-converting enzyme 2 [ACE2] receptors and fuse the viral and host
Fig. 1 Structure of Coronavirus (Representing the different parts of the coronavirus)

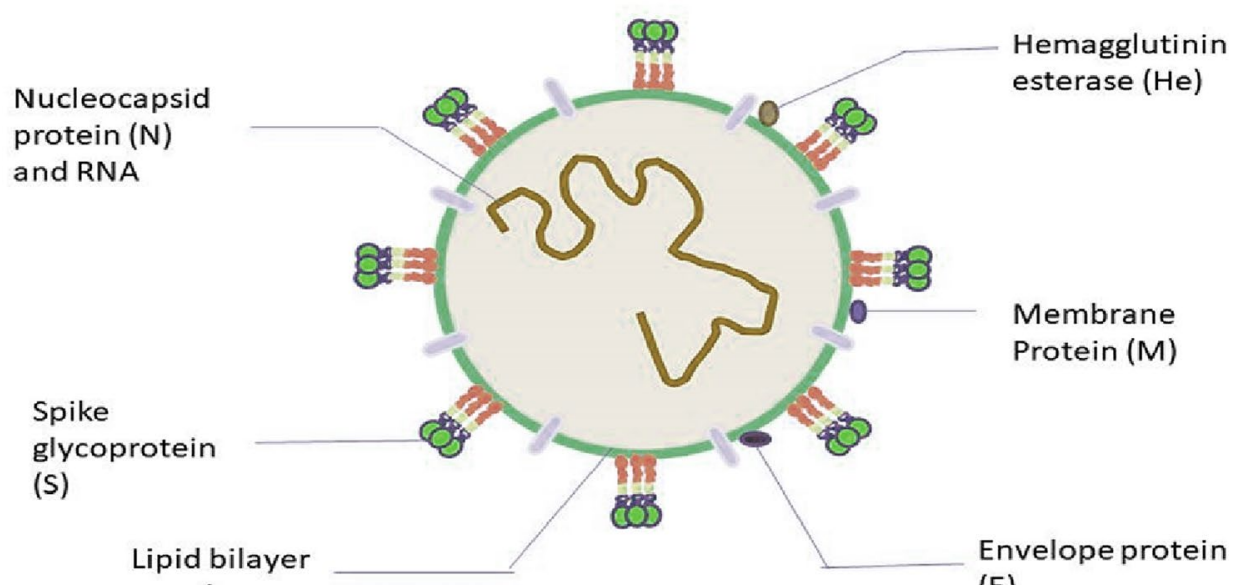

(E) 
cell membranes as shown in Figs. 2 and 3. The spike can evade the surveillance of the host immune system while entry due to the polysaccharide molecular coating that camouflages it (Watanabe et al. 2020a). The homo-trimeric spike [S] glycoprotein is present in two distinct structural states: pre-fusion and post-fusion ( $\mathrm{Li} 2016)$ and is highly conserved among all human coronaviruses.

In SARS-CoV, and MERS-CoV, the S protein is unstable in their metastable pre-fusion state (Pallesen et al. 2017; Millet and Whittaker 2018). The two main functional subunits of S protein of SARS-CoV-2, namely S1 and S2, that contains the extracellular domain [ECD] and a transmembrane helix (Hoffmann et al. 2020a) that are non-covalently linked in a pre-fusion state (Walls et al. 2020; Wan et al. 2020; Tortorici and Veesler 2019). The structure of the spike protein is shown in Fig. 4. These are further divided into three chief topological domains, the head, the cytoplasmic tail [CT], and the stalk. The head part of the SARS-CoV-2 S protein involves multiple domains as obtained from numerous recently published structural studies (Watanabe et al. 2020a; Walls et al. 2020). The S1 subunit aids in receptor binding. It consists of two domains: the N-terminal domain and the C-terminal receptor-binding domain [RBD] (Li 2020). The $\mathrm{C}$-terminal domain consists of the receptor-binding motif $[\mathrm{RBM}]$ that is responsible for interaction with the ACE2 receptor (Wang et al. 2020a). The S1 part comprising the N-terminal domain [NTD] and the 200-amino-acid-long RBD aids in the determination of host ranges and tissue tropism (Walls et al. 2020; Li 2015; Yan et al. 2020; Lu et al. 2015; Wrapp et al. 2020). The S2 subunit which promotes fusion of the viral membrane with the cellular host membrane (Hoffmann et al. 2018; Hulswit et al. 2016; Millet and Whittaker 2018), consists of the fusion peptide [FP], hepta-peptide repeat sequence 1 [HR1], HR2, transmembrane [TM], and cytoplasmic domain [CD] (Xia et al. 2020). Cryo-electron microscopy or X-ray experiments do not resolve domains of the $\mathrm{S} 2$ subunit in a pre-fusion state, such as HR2 and TM domains, that forms the stalk and the CT.

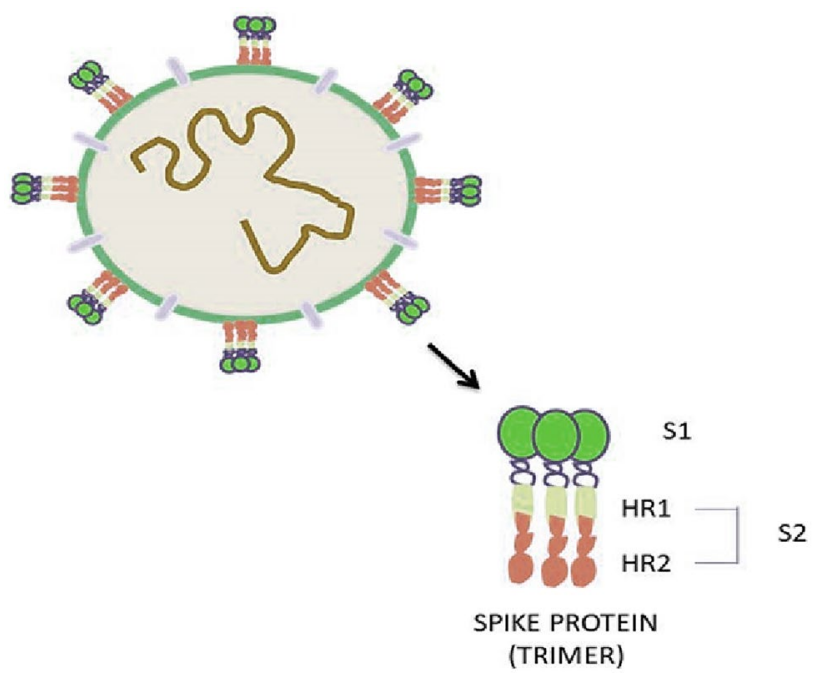

Fig. 4 Schematic structure of Spike protein (Spike protein made up of two units S1 and S2 while S2 unit made up 2 sub-units HR1 \& HR2)

Considerable conformational changes occur, as S1 engages the 805-amino-acid-long human angiotensinconverting enzyme 2 [hACE2] (Li 2015; Yan et al. 2020; $\mathrm{Lu}$ et al. 2015; Towler et al. 2004) receptor of the host cell through the exposed RBD of SARS-CoV-2 and the extracellular domain of ACE2 for receptor binding. The function of NTD, on the other hand, is not well realized. NTD might have a crucial role in the transition of $\mathrm{S}$ protein from pre-fusion to the post-fusion stage and also recognition of certain sugar moieties on interaction in some coronaviruses (Lu et al. 2015; Krempl et al. 1997; Künkel and Herrler 1993; Zhou et al. 2019).

hACE2 encompasses two functional domains, first the $\mathrm{N}$-terminal peptidase M2 domain and the latter C-terminal collectrin domain. There are further two catalytic subdomains along with an active site located between the two subdomains in the peptidase domain (Towler et al. 2004).

Similar to SARS-CoV, RBD of SARS-CoV-2 S protein also consists of two subdomains: core and extended loop. the co-crystal structures of SARS-CoV and SARS-CoV-2
Fig. 3 Process of fusion of virus $\mathrm{S}$ protein and the host receptor

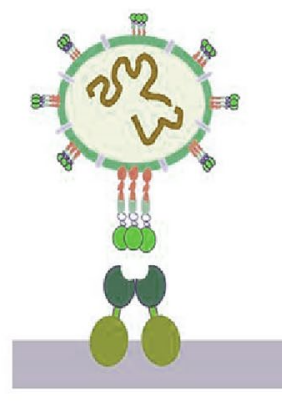

Native state

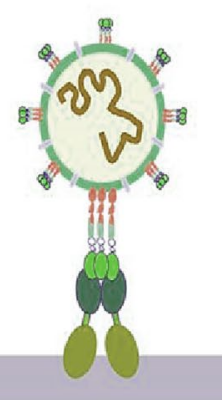

Binding

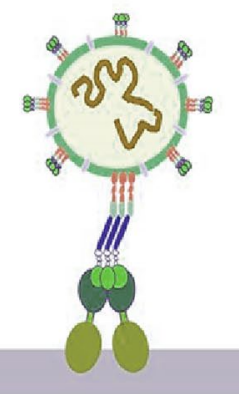

Intermediate

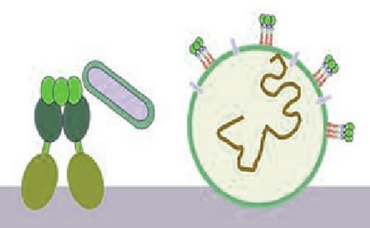

Cell fusion 
S proteins attached with ACE2 demonstrated that the extended loop of RBD directly binds to loops flanked by 2 and 3 helices and a hairpin loop between 3 and 4 sheers of ACE2 receptor (Yan et al. 2020; Li et al. 2005). In the infection of a cell, the $\mathrm{S}$ protein-membrane binding is activated by specific cellular enzymes like trypsin, furin, cathepsin (Jaimes and Whittaker 2018; Li et al. 2017; Millet and Whittaker 2015). Genomic analysis has displayed that the $\mathrm{S}$ protein of SARS-CoV-2 is distinct from other viruses (Li 2016; Du et al. 2017), showing that a site in S protein is activated by an $\mathrm{HC}$ enzyme called furin as shown in Fig. 5 (Millet and Whittaker 2015). On attachment of RBD and cell surface hACE2 receptor, shedding of S1 protein from $S 2$ protein takes place alongside its cleavage at the novel furin S1/S2 site by host cell proteases, such as the transmembrane serine protease, TMPPRSS2 (Watanabe et al. 2020a; Hoffmann et al. 2020a) that mediates cell entry and thought to prime the spike for protein (Davidson et al. 2020; Belouzard et al. 2009). Another proteolytic cleavage at S2' site leads to the release of the fusion protein [FP] that penetrates the host cell membrane and facilitates fusion (Apellániz et al. 2014). Thus, the enzymes responsible can also serve as potential targets for anti-viral action. External factors including protein digestion (Walls et al. 2019; Walls et al. 2017), receptor binding, and antibody binding (Walls et al. 2019) lead to the transitional change of $\mathrm{S}$ protein into a post-fusion state. This promotes the virus-host cell membrane fusion due to the exposure of a fusion peptide adjacent to the S2' proteolysis site, as well as the RNA virus release and entry, with the $\mathrm{S}$ protein folding to a post-fusion conformation (Tortorici and Veesler 2019; Walls et al. 2017; Madu et al. 2009; Millet and Whittaker 2014). Thus, this makes RBD a potential target for neutralizing antibodies in the development of therapeutic interventions for COVID-19, due to its vital role in the initiation of entry of SARS-CoV-2 (Watanabe et al. 2020a, b). On entering the virus into the host cell, the viral genome is released, and the RNA genome translates polyproteins, forming non-structural proteins [nsps] from two open reading frames [ORFs] once it enters the host cell. Furthermore, it is also used as a template through
RNA-dependent RNA polymerase activity for the process of replication and translation (Fig. 6).

Proteolytic cleavage results in replication and transcription process and assembly of replicase-transcriptase complex. Once the viral RNA is replicated and structural proteins are synthesized, assembled, and packaged in the host cell, the viral proteins are released (Li et al. 2005).

While SARS-CoV and SARS-CoV-2 show a high level of similarity (Chen et al. 2020) with S protein binding to the human angiotensin-converting enzyme 2 [ACE2] receptor, the Middle East respiratory syndrome [MERS]-CoV spike protein interacts with dipeptidyl peptidase 4 [DPP4] (Li 2015; Yan et al. 2020) which exhibits its low homology toward that of SARS-CoV in the RBD domain. Further, on structural analysis, the residue sequence identity of SARS$\mathrm{CoV}$ and SARS-CoV-2 viruses showed $72 \%$ similarity.

The affinity of binding of spike protein to angiotensinconverting enzyme 2 [ACE2] cognate receptor in SARSCoV-2 is 10-22-fold higher as compared to SARS-CoV (Wrapp et al. 2020; Lan et al. 2020; Shang et al. 2020). the reason attributed for the same is the presence of more contacts in the interface that covered a larger surface area (Brielle et al. 2020) and also the presence of three hotspots for the mutation in the $\mathrm{S}$ protein that results in a more compact and specific conformation (Brielle et al. 2020; Ou et al. 2020). According to molecular modeling studies, a distinct Phe residue plays a crucial role in the binding site owing to its interaction with the ACE2 receptor. Additionally, the furin protease cleavage site at $\mathrm{S} 1 / \mathrm{S} 1$ also differentiates SARS-CoV-2 from SARS-CoV or other similar bat coronaviruses (Hoffmann et al. 2020a, b; Matsuyama et al. 2020).

\section{Potential covalent spike protein inhibitors}

To save COVID-19 patients, it is important to identify potential and effective drugs that could target SARS-CoV-2. The de novo drug development would take over 15 years from target identification followed by drug validation, then hit discovery followed by lead optimization and further preclinical and clinical trials (Kaitin 2010b). This is not possible
Fig. 5 Proteolytic Activation Of Coronavirus By Furin

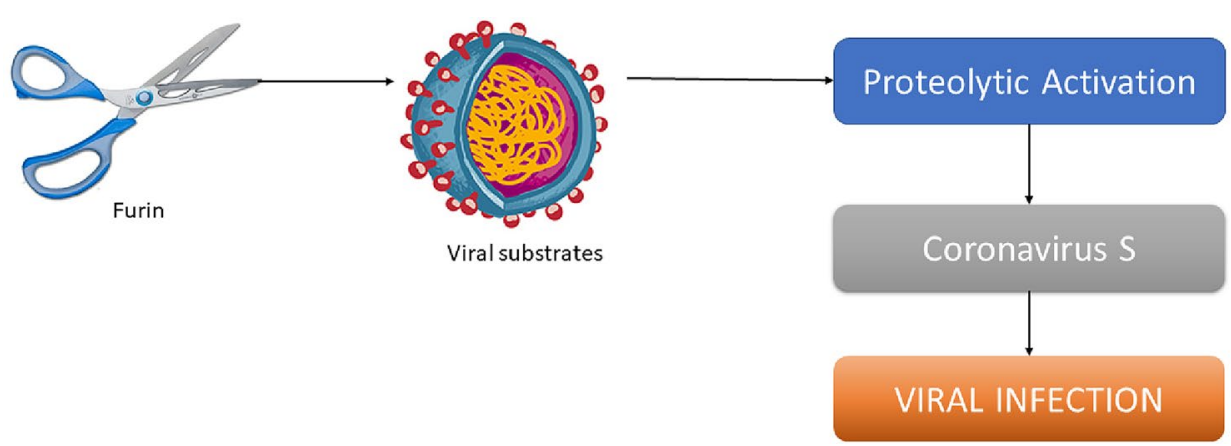




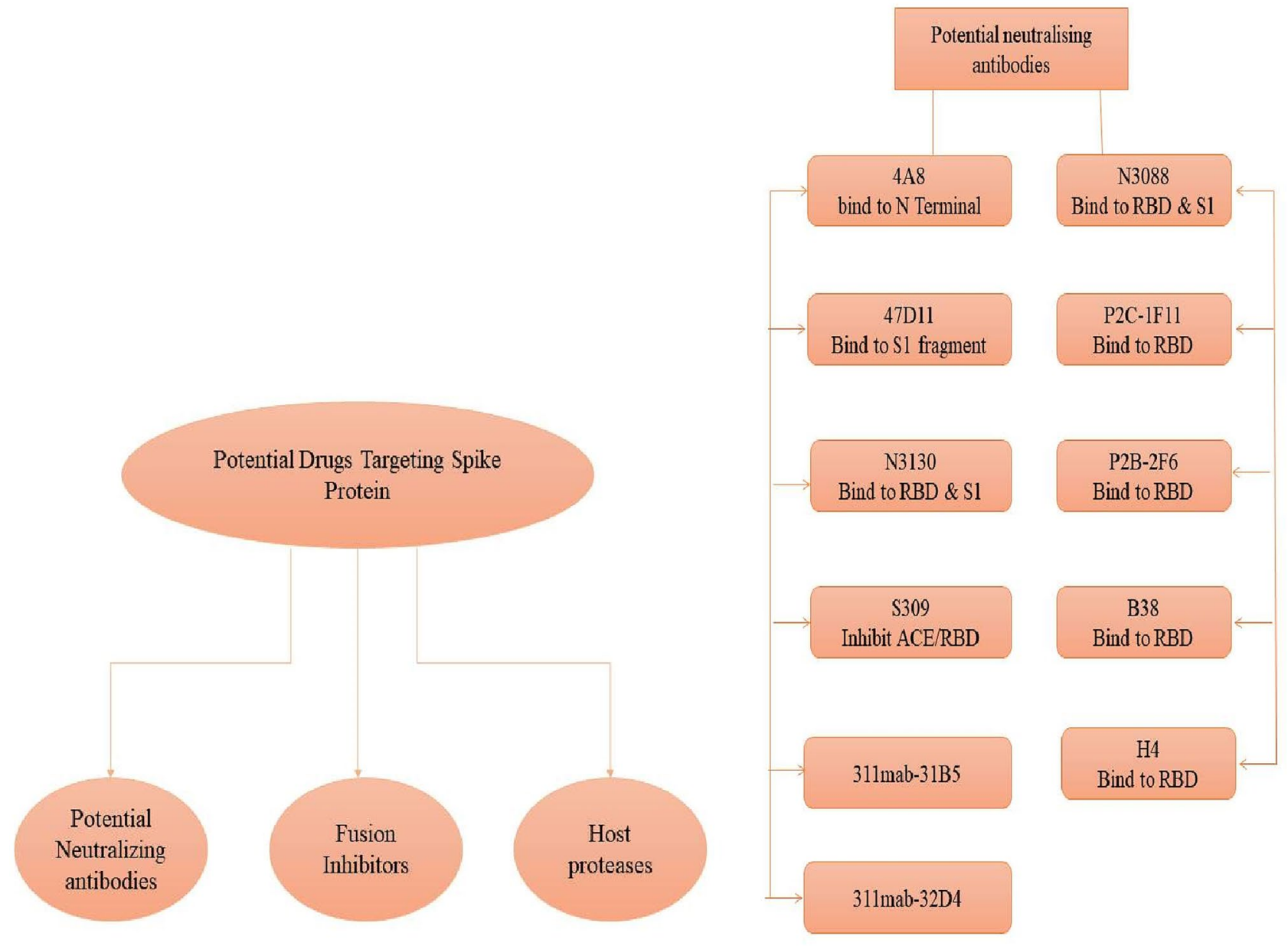

(a)

(b)

Fig. 6 (132): a Current classes of potential SARS-CoV-2 inhibitors; b potential neutralizing antibodies and their mechanism; c Fusion inhibitors and their mechanism; $\mathbf{d}$ Host protease inhibitors and mechanism

in the time frame of coronavirus pandemic and hence the most appropriate approach for the same would be drug repurposing.

Remdesivir, an experimental drug developed to treat the Middle East respiratory syndrome coronavirus [MERS$\mathrm{CoV}]$, has been reported to be effective in treating several COVID-19 cases but still lacks clinical data support but undergoing clinical study in Wuhan, China. Likewise, chloroquine, ritonavir/lopinavir, and many other drugs lack the support of clinical data but have been reported as a potential therapeutic against SARS-CoV-2 (Maxmen 2020). Several drugs including Ritonavir [antiviral drug] Remdesivir [RdRp inhibitor], Camostat [TMPRSS2 inhibitor], as well as Azithromycin [an antibiotic], and Chloroquine/Hydroxychloroquine [antimalarials] are currently undergoing clinical trials for the determination of their action against SARS-CoV-2. Additionally, many pieces of research are published so far that report numerous promising and potential compounds against COVID-19 (Zhang and Wu 2020; Ekins et al. 2020; Ge et al. 2020).

A recent study was conducted by QizhangLi and colleagues using SCARdock to computationally screen potential candidates inhibiting CatB, CatL, and TMPRSS2 covalently. The study identified five potential inhibitors of CatB that are neratinib, [Z]-dacomitinib, trapoxin B, HKI-357, and domatinostat and four TMPRSS2 potential inhibitors including [S]-boceprevir, [R]-boceprevir, aceneuramic acid, and lodoxamide. Moreover, trapoxin B (Kijima et al. 1993), HKI-357 (Tsou et al. 2005), neratinib (Tsou et al. 2005), [Z]-dacomitinib (Garuti et al. 2011) and boceprevir (Nazario de Moraes et al. 2019) have already proven to be covalent inhibitors ( $\mathrm{Li}$ and Wang 2020). Some other potential spike protein inhibitors (Table 1) are given in details as follows: 


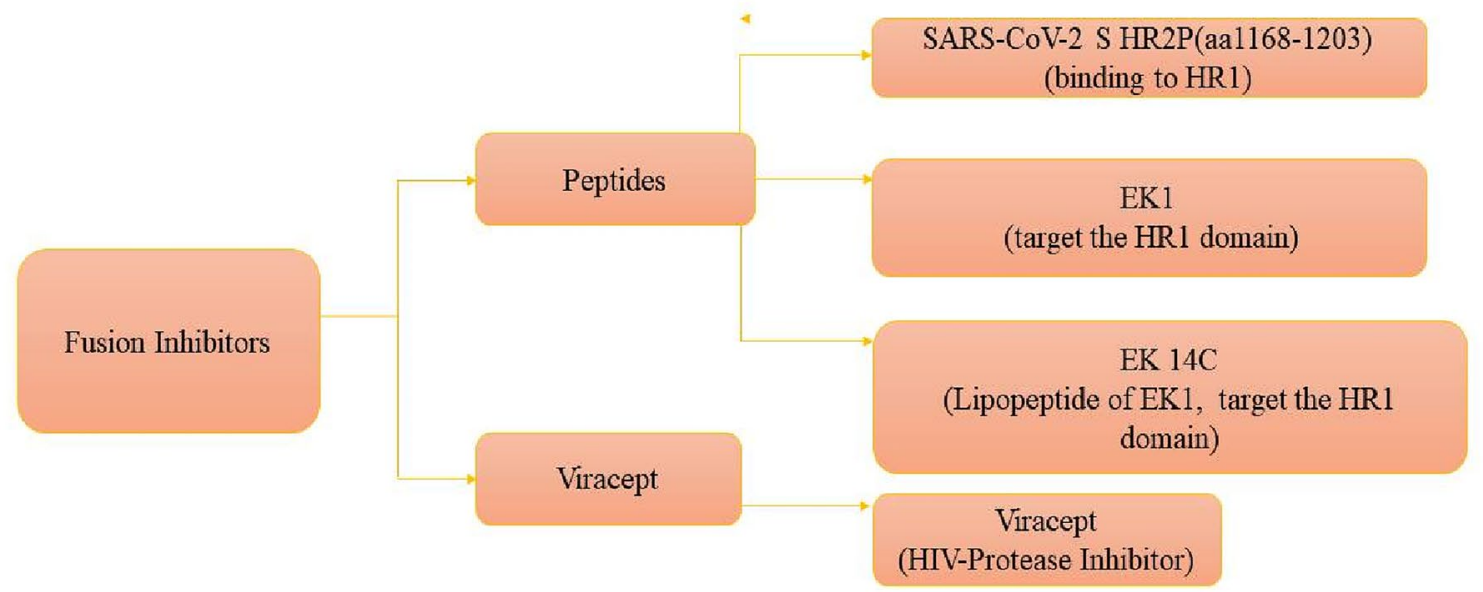

(c)

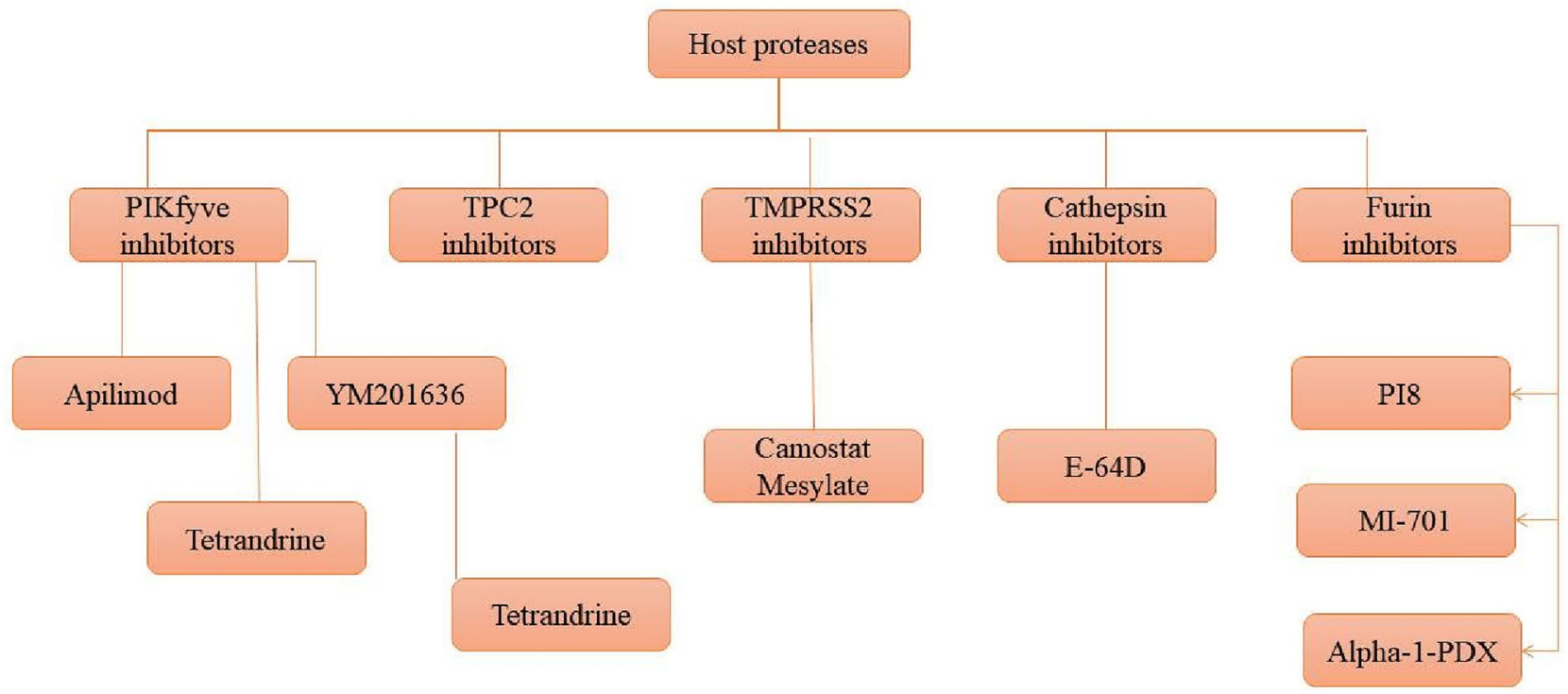

(d)

Fig. 6 (continued)

\section{Ribavirin}

Ribavirin is a guanosine analog compound that obstructs the replication of both RNA and DNA viruses by inhibiting the RNA-dependent RNA polymerase. Additionally, ribavirin also acts by hindering with RNA capping that depends on natural guanosine to thwart RNA degradation. It destabilizes the viral RNA by inhibiting natural guanosine generation via directly restraining inosine monophosphate dehydrogenase, which is essential for producing guanine precursor to guanosine (Graci and Cameron 2006). Due to the limited proven capacity as an effective therapeutic agent during MERS-CoV and SARS-CoV outbreaks, clinical testing for ribavirin on SARS-CoV-2 is lacking and limited (Khalili et al. 2020). According to previous studies investigating the handling of MERS-CoV and SARS-CoV infection, the most familiar complication in the treatment with ribavirin is anemia (Knowles et al. 2003; Yousefi et al. 2020; Omrani 
Table 1 Some potential spike protein inhibitors and their structures

\begin{tabular}{lll}
\hline Sr. No & Drug & Structures \\
\hline 1 & Trapoxin B
\end{tabular}

2 Neratinib

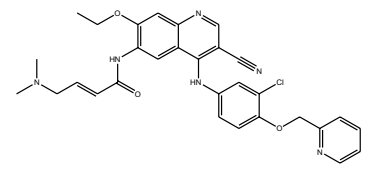

3

Domatinostat

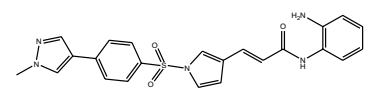

4

[Z]-Dacomitinib

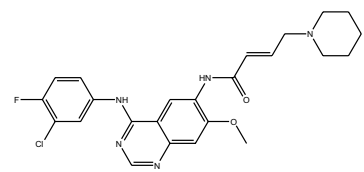

5

Lodoxamide<smiles>N#Cc1cc(NC(=O)C(=O)O)c(Cl)c(NC(=O)C(=O)O)c1</smiles>

6

Aceneuramic acid<smiles>CC(=O)N[C@H]1C([C@H](O)[C@H](O)CO)O[C@](O)(C(=O)O)C[C@H]1O</smiles>

7

Boceprevir

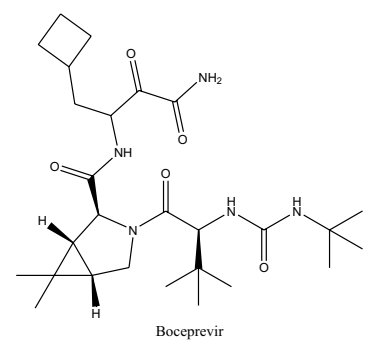

8

Remdesivir

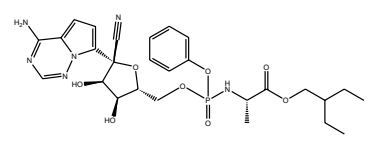

$9 \quad$ Afatinib

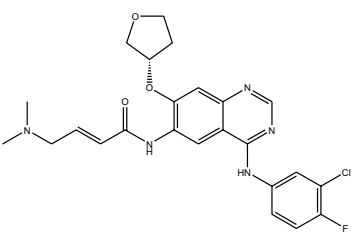

Mechanism of action

Inhibit histone deacetylases (HDACs) by alkylating the enzyme

Irreversibly binds to the intercellular signaling domain of HER1, HER2, HER3, and epithelial growth factor receptor, and inhibits phosphorylation and several HER downstream signaling pathways

Inhibits the enzymes histone deacetylase (HDAC) 1, 2, and 3

Irreversible inhibitor of human epidermal growth factor receptor (EGFR) family (EGFR/HER1, HER2, and HER4) tyrosine kinases activity

Mast cell stabilizer, inhibits the release of intracellular histamine

Unknown

Viral protease inhibitors

Inhibits the RNA-dependent RNA polymerase (RdRp)

Inhibits human epidermal growth factor receptor 2 (Her2) and epidermal growth factor receptor (EGFR) kinases 
Table 1 (continued)

\begin{tabular}{|c|c|c|c|}
\hline Sr. No & Drug & Structures & Mechanism of action \\
\hline 10 & Arbidol & & Block trimerization of the spike glycoprotein in corona viruses \\
\hline 11 & Curcumin & & inhibit Endosomal acidification and processing of the viral proteins \\
\hline 12 & Chemostat mesylate & & Serine protease TMPRSS2 inhibitor \\
\hline 13 & Emodin & & Tyrosin kinase p65lck inhibitor \\
\hline 14 & Nafamostat & & Inhibit serine protese \\
\hline 15 & $\begin{array}{l}\mathrm{N} \text {-[2-Aminoethyl]-1 } \\
\text { Aziridine-ethan- } \\
\text { amine }\end{array}$ & & $\begin{array}{l}\text { Bind with ACE2 which may lead to a conformational change in ACE2 receptor, } \\
\text { that shift residues which bind SARS-CoV S-glycoprotein and hence prevent } \\
\text { viral attachment and entry }\end{array}$ \\
\hline 16 & Imatinib & & Inhibit bcr-abl tyrosine kinase \\
\hline
\end{tabular}

et al. 2014). Reduced in vitro potency in comparison to its comparative therapeutic agents was suggested by researchers (Wang et al. 2020b). Moreover, dose-dependent adverse reactions like the toxicity of liver and blood were found in clinical studies of ribavirin therapy for SARS-CoV (Sanders et al. 2019). However, in a randomized and open-labeled phase 2 clinical trial study, it was proven that triple antiviral treatment with interferon beta- $1 \mathrm{~b}$ that is lopinavir, ritonavir, and ribavirin was more effective and as compared to ritonavir-lopinavir alone in relieving symptoms, curbing the duration of virus shedding, and a hospital stay of COVID-19 patients with moderate to mild symptoms (Hung et al. 2020; Huang 2020).

While several in vitro studies have indicated the effective activity against SARS-CoV, many studies concluded that ribavirin did not prove to hinder the virus in vivo and also did not boost SARS-CoV-infected patient's recovery (Barnard et al. 2006; Lee et al. 2004). These inconclusive researches demonstrate the inefficiency of ribavirin as a beneficial agent against COVID-19.

Although, in the case of combination therapy, ribavirin may provide enhanced clinical efficiency (Sanders et al.
2019; Yousefi et al. 2020; Zhong et al. 2020). The administration of ribavirin for SARS-CoV-2 infection necessitates further research on the same.

\section{Umfenovir}

Umfenovir, also known as Arbidol is an indole derivative approved for both the prophylaxis and therapy of influenza A and B in China and Russia (Sanders et al. 2019; Wu et al. 2020b). It acts by suppressing the influenza virus spread and controlling the expression of inflammatory cytokines both in vitro and in vivo (Wang et al. 2017). Moreover, it has exhibited potent broad-spectrum antiviral action against both enveloped and non-enveloped viruses, such as Ebola virus, hepatitis $C$ virus, hepatitis $B$ virus, Lassa virus, human herpesvirus 8, and poliovirus (Blaising et al. 2014; Boriskin et al. 2008; Herod et al. 2019; Pecheur et al. 2016). It shows its action by interfering with numerous stages of the virus life cycle by targeting virus-associated host factors or viral proteins (Blaising et al. 2014). In the influenza virus, Arbidol binds to hemagglutinin [HA], the chief cell surface glycoprotein, and prevents the viral membrane binding 
(Kadam and Wilson 2017). Arbidol competently inhibits SARS-CoV-2 infection and has been recognized as a potential therapy for novel SARS-CoV-2 infection.

Both the entry of the virus and the post-entry stages are blocked by Arbidol as it hinders the binding of the virus to host cells and intracellular vesicle trafficking (Wang et al. 2020c). Thus, it prevents the fusion of the membrane of the viral by targeting the engagement between viral $\mathrm{S}$ proteins and ACE2 receptors. A retrospective study of February 2020, China, depicted an undetectable viral load in 16 patients administered with umifenovir [ $200 \mathrm{mg}$ TID], in comparison to a $44.1 \%$ viral load detection in patients treated with lopinavir-ritonavir monotherapy [ $400 \mathrm{mg} / 100 \mathrm{mg}$ BID] (Zhu et al. 2020). Similarly, another retrospective cohort study including 16 COVID-19 patients, who were administered with umifenovir and lopinavir-ritonavir or lopinavir-ritonavir monotherapy showed undetectable SARS-CoV using RT-PCR after 14 days of administration in $94 \%$ of patients. While only $53 \%$ of the control group showed undetectable SARS-CoV. Additionally, the umifenovir experimental group displayed chest improvement, as assessed by CT scans [ $69 \%$ compared to $29 \%$ in lopinavir-ritonavir monotherapy]. Therefore, it can be implied that umifenovir may be more effectual than lopinavir-ritonavir in treating COVID-19 (Deng et al. 2020).

\section{Dacomitinib}

Dacomitinib is a second-generation tyrosine kinase inhibitor [TKI] that results in inhibition of the activity of tyrosine kinase inside the cells. It shuts the downstream signaling pathways. Originally, it was used in oncology trials and the treatment of malignancies, and initial studies on TKIs were conducted to observe their potential in targeting the epidermal growth factor [EGFR] family (Ciardiello and Tortora 2008; Sim et al. 2018).

It was suggested that increased fibrotic responses due to the damage to the lungs in SARS infection are prevented by the blockade of EGFR signaling (Venkataraman and Frieman 2017). Dacomitinib, as a potent EGFR TKI irreversibly binds to the receptors and exhibits a strong cellular potency against EGFR oncogenic variants (Deeks and Keating 2018). In silico screening of dacomitinib in addition to neratinib and domatinostat as a cathepsin-binding drug that targets viral and host, proteins have also been reported ( $\mathrm{Li}$ et al. 2020).

\section{Nafamostat}

Nafamostat is a broad-spectrum serine protease inhibitor possessing significant anti-coagulant and anti-inflammatory effects that help in inhibiting coagulation factor X, coagulation factor XII, prothrombin, Kallikrein-1, Trypsin 1, and
ICAM-1 (Kim et al. 2016). Approved in South Korea and Japan to treat disseminated intravascular coagulation [DIC], pancreatitis and for hemodialysis procedures, nafamostat is a promising agent for the treatment of COVID-19 (Choi and Kang 2015; Kimura et al. 2020). It blocks the entry of SARS-CoV-2 inside the host cell by preventing the fusion of the virus envelope with the human cell (Hoffmann et al. 2020c; Yamamoto and Kiso 2020). Similar to camostat, the action is brought by interacting with Asp435, Ser441, and His 296 residues of the TMPRSS2 gene and its inhibition (Sonawane et al. 2020a). In Calu-3 lung cells, it reduces the rate of implantation of MERS-CoV and SARS-CoV-2 (Hoffmann et al. 2020a, c; Yamamoto and Kiso 2020; Yamamoto et al. 2016). Moreover, recent evidence exhibits that COVID-19 can be problematic with coagulopathy, particularly DIC (Kollias et al. 2020). Thus, its anti-coagulant and anti-viral properties may help in the management of COVID19 patients with coagulopathy (Asakura 2020). A case report demonstrated that the combination therapy with nafamostat and heparin is more efficient than heparin monotherapy in stopping circuit thrombosis during venous-venous extracorporeal membrane oxygenation [VV-ECMO] (Doi et al. 2020a).

Also, in combination with favipiravir, nafamostat mesylate may be efficient for severely ill COVID-19 patients as it may allow blockade of virus entry and replication along with the inhibition of pathogenic host reaction, including hyper-coagulopathy (Doi et al. 2020b).

\section{Afatinib}

Host-targeting antivirals that use deep neural networks [DNN] were made and tested against the coronaviruses. One of the numerous drugs recognized for anti-SARS-CoV-2 activity using deep neural networks is afatinib (Avchaciov et al. 2020). Afatinib is a small molecule tyrosine kinase inhibitor [TKI] targeting the epidermal growth factor receptor [EGFR].

EGFR, involved in initiating the critical downstream signaling pathways, promotes cell propagation and angiogenesis and reduces metastasis and apoptosis (Scagliotti et al. 2004). Clinical findings suggest that non-small lung cancer patients displayed an elevated risk of interstitial lung disease [ILD], a prognostic indication of pulmonary fibrosis, while on treatment with EGFR-TKIs (Kato and Nishio 2006). A SARS-CoV-2 viral infection will notably worsen the lung damage and likely lead to severe pneumonia of a patient who is already showing adverse signs of ILD after taking EGFR-TKIs treatment. Thus, it is imperative to straightaway discontinue TKIs drug therapy and start active anti-viral treatment in such patients (Cai et al. 2020). Additionally, clinical studies show afatinib to be able to be safely administered along with a multitude of anti-viral agents (Dunn et al. 
2018; Wind et al. 2014). Afatinib was examined with ribavirin and standard chemotherapy (Dunn et al. 2018) in a phase I clinical study using human papillomavirus [HPV] head and neck squamous carcinoma cell and the anti-inflammatory and anti-fibrotic activity was determined (Hardie et al. 2008; Beyer et al. 2010; Chen et al. 2019).

It is suggested that afatinib can be explored as a potential drug in combination with various anti-virals for the management of COVID-19.

\section{$\mathrm{N}$-[2-aminoethyl]-1 aziridine-ethanamine [NAAE]}

Molecular docking studies and structure-based in silico analysis have identified N-[2-aminoethyl]-1 aziridine-ethanamine as a potent ACE2 inhibitor of SARS-CoV S proteinmediated cell fusion (Huentelman et al. 2004). These specific peptide inhibitors can be used to target the host receptor and prevent viral entry.

Thus, inhibitors that interfere with the interaction of RBD with ACE2, such as NAAE, a small molecule inhibitor can prove to be of therapeutic importance. However, tests have not been conducted using these inhibitors on COVID-19 patients.

\section{Camostat}

Similar to nafamostat, camostat mesylate is another serine protease inhibitor used for the treatment of pancreatitis and reflux disease in Japan that hampers the infection caused by the SARS-CoV-2 virus in the lungs (Hoffmann et al. 2020a). Plasmin, Thrombin, and Kallikrein are blocked as Camostat restricts Trypsin (Ramsey et al. 2019). Also, the rate of infection of Calu-3 lung cells by the virus is decreased.

It interferes with the TMPRSS2 gene activity whose main function is the priming of $\mathrm{S}$ protein of SARS-CoV-2 and promoting the entry of the virus via the ACE2 receptor. Thus, chemostat mesylate can be examined as a capable anti-TMPRSS2 agent (Hoffmann et al. 2020a). Few tolerable adverse effects related to camostat including pruritus, lightheadedness, and increase in thirst and appetite have been reported (Ramsey et al. 2019). Additionally, several studies showed that camostat mesylate is rapidly converted into its active metabolite, 4-[4 guanidinobenzoyloxy] phenylacetic acid [GBPA] in humans and animals. GBPA further gets metabolized into the inactive metabolite 4-guanidinobenzoic acid [GBA]. The capability of GBPA to confine the enzymatic activity of TMPRSS2, however, has not been studied (Beckh et al. 1987, 1991; Midgley et al. 1994; Ohki et al. 1980). It was demonstrated that camostat mesylate more strongly inhibits TMRSS2 in comparison to nafamostat and bromhexine hydrochloride (Sonawane et al. 2020b).

\section{Emodin}

Emodin belongs to the genus Rheum and Polygonum and is an anthraquinone phytochemical that potentially prevents the interaction between ACE2 host receptor and SARS-CoV. It is revealed that emodin lowers the chances of coronavirus infection as it inhibits the spike protein of the virus (Ho et al. 2007). Additionally, Schwarz et al. and colleagues in a recent study found that emodin blocks the $3 \mathrm{a}$ ion channel of both SARS coronavirus and human coronavirus OC43 and thus offers a basis for the observed reduction in the release of the virus (Schwarz et al. 2011). On the other hand, according to a recent study conducted by Kern DM et al. and colleagues, they found that purified 3 a channel activity was not affected by emodin, and no emodin electron density was detected in their singleparticle cryo-EM trial of 3 a proteins in the presence of the compound (Kern et al. 2020). Besides its anti-viral, anti-inflammatory, anti-cancer, and anti-bacterial properties, emodin involves toxic effects including hepatotoxicity, nephrotoxicity, genotoxicity, and reproductive toxicity (Dong et al. 2016; Dewanjee et al. 2020). Consequently, emodin can be a capable therapeutic candidate for drugs targeting SARS-CoV-2 (Zhou et al. 2020). However, the limited information and lack of research impede proper studies on emodin as potential drug therapy.

\section{Conclusion}

SARS-CoV-2 virus has not only brought health crisis, but also proved to be an unprecedented threat to the economy worldwide. The lack of effective therapy and preventive measures is the main alarming sign so far. The de novo synthesis and discovery of the drug would take several years; hence, the most effective way to tackle the situation is repurposing a drug that would not only reduce the time of drug discovery, but also the cost.

One of the main targets of therapeutics against COVID19 is the inhibition of spike protein as it aids in both the recognition and binding of the virus to the host cell. Some of the therapeutic agents that have the potential against the spike protein are Ritonavir [antiviral drug] Remdesivir [RdRp inhibitor], Camostat [TMPRSS2 inhibitor], as well as Azithromycin [an antibiotic], and Chloroquine/ Hydroxychloroquine [antimalarials]. Though, the exact potential needs to be proved and necessitates further clinical studies. 
Funding This research did not receive any specific grant from funding agencies in the public, commercial, or not-for-profit sectors.

\section{Declarations}

Conflict of interest Authors are not having any kind of financial and personal advantage.

\section{References}

Apellániz B, Huarte N, Largo E, Nieva JL (2014) The three lives of viral fusion peptides. Chem Phys Lipids 181:40-55

Asakura H (2020) Ogawa H Potential of heparin and nafamostat combination therapy for COVID-19. J Thromb Haemost 18:1521-1522

Avchaciov K, Burmistrova O, Fedichev PO (2020) AI for the repurposing of approved or investigational drugs against COVID-19. https://www.researchgate.net/profile/Peter-Fedichev/publication/ 339998830_AI_for_the_repurposing_of_approved_or_investigat ional_drugs_against_COVID-19/links/5e71c42d299bf1571845 af01/AI-for-the-repurposing-of-approved-or-investigationaldrugs-against-COVID-19.pdf. Accessed 15 Jan 2021

Baker NC, Ekins S, Williams AJ, Tropsha A (2018) A bibliometric review of drug repurposing. Drug Discov Today 23:661-672. https://doi.org/10.1016/j.drudis.2018.01.018

Barnard DL, Day CW, Bailey K, Heiner M, Montgomery R, Lauridsen L et al (2006) En- hancement of the infectivity of SARS-CoV in BALB/c mice by IMP dehydroge- nase inhibitors, including ribavirin. Antiviral Res 71:53-63. https://doi.org/10.1016/j.antiv iral.2006.03.001

Beckh K, Goke B, Muller R, Arnold R (1987) Elimination of the lowmolecular weight proteinase inhibitor camostate (FOY 305) and its degradation products by the rat liver. Res Exp Med (berl) 187:401-406

Beckh K, Weidenbach H, Weidenbach F, Muller R, Adler G (1991) Hepatic and pancreatic metabolism and biliary excretion of the protease inhibitor camostat mesilate. Int J Pancreatol 10:197-205

Belouzard S, Chu VC, Whittaker GR (2009) Activation of the SARS coronavirus spike protein via sequential proteolytic cleavage at two distinct sites. Proc Natl Acad Sci USA 106(14):5871-5876

Beyer C, Distler JH, Distler O (2010) Are tyrosine kinase inhibitors promising for the treatment of systemic sclerosis and other fibrotic diseases? Swiss Med Wkly 140:w13050

Blaising J, Polyak SJ, Pecheur EI (2014) Arbidol as a broad-spectrum antiviral: an update. Antiviral Res 107:84-94. https://doi.org/10. 1016/j.antiviral.2014.04.006 (Epub 2014/04/29)

Boriskin YS, Leneva IA, Pecheur EI, Polyak SJ (2008) Arbidol: a broad-spectrum antiviral compound that blocks viral fusion. Curr Med Chem 15(10):997-1005. https://doi.org/10.2174/09298 6708784049658 (PubMed PMID: 18393857)

Brielle ES, Schneidman-Duhovny D, Linial M (2020) The SARSCoV-2 exerts a distinctive strategy for interacting with the ACE2 human receptor. Viruses 12(5):497

Cai Y, Xu Y, Xu D et al (2020) Considerations in treating patients with advance lung cancer during the epidemic outbreak of novel coronavirus (SARS-CoV-2). Med Oncol 37(9):78. https://doi. org/10.1007/s12032-020-01401-w

Cascella M, Rajnik M, Aleem A, Dulebohn SC, Napoli RD (2021) Features, evaluation and treatment of coronavirus (COVID-19), Statpearls. https://www.statpearls.com/ArticleLibrary/viewarticle/52171. Accessed12 Jan 2021

Chen YJ, Hsu CC, Shiao YJ, Wang HT, Lo YL, Lin AMY (2019) Antiinflammatory effect of afatinib (an EGFR-TKI) onOGD-induced neuroinflammation. Sci Rep 9(1):2516
Chen Y, Guo Y, Pan Y, Zhao ZJ (2020) Structure analysis of the receptor binding of SARS-CoV-2. Biochem Biophys Res Commun 525(1):135-140. https://doi.org/10.1016/j.bbrc.2020.02. 071

Chen F, Lou D (2020) Rising concern on damaged testis of COVID 19 patients. Urology 142:42. https://doi.org/10.1016/j.urology. 2020.04 .069

Choi JY, Kang YJ, Jang HM et al (2015) Nafamostat mesylate as an anticoagulant during continuous renal replacement therapy in patients with high bleeding risk: a randomized clinical trial. Medicine 94:e2392

Ciardiello F, Tortora G (2008) EGFR antagonists in cancer treatment. N Engl J Med 358:1160-1174

Coronavirus research centre, Johns Hopkins University \& Medicine. https://coronavirus.jhu.edu. Accessed 13 Aug 2021

Cuesta A, Wan X, Burlingame AL, Taunton J (2020) Ligand conformational bias drives enantioselective modification of a surfaceexposed lysine on Hsp90. J Am Chem Soc 142:3392-3400. https://doi.org/10.1021/jacs.9b09684

Davidson AD, Williamson MK, Lewis S, Shoemark D, Carroll MW, Heesom KJ, Zambon M, Ellis J, Lewis PA, Hiscox JA, Matthews DA (2020) Characterisation of the transcriptome and proteome of SARS-CoV-2 reveals a cell passage induced in- frame deletion of the furin-like cleavage site from the spike glycoprotein. Genome Med 12(1):68

Deeks ED, Keating GM (2018) Afatinib in advanced NSCLC: a profile of its use. Drugs Ther Perspect 34:89-98

Deng L, Li C, Zeng Q, Liu X, Li X, Zhang H, Hong Z, Xia J (2020) Arbidol combined with LPV/r versus LPV/r alone against Corona Virus Disease 2019: a retrospective cohort study. J Infect. https:// doi.org/10.1016/j.jinf.2020.03.0024

Dewanjee S, Chakraborty P, Mukherjee B, De Feo V (2020) Plantbased antidiabetic nanoformulations: the emerging paradigm for E_ective therapy. Int J Mol Sci 21:2217

Doi S, Akashi YJ, Takita M et al (2020a) Preventing thrombosis in a COVID-19 patient by combinatorial therapy with nafamostat and heparin during extracorporeal membrane oxygenation. Acute Med Surg. https://doi.org/10.1002/ams2.585

Doi K, Ikeda M, Hayase N et al (2020b) Nafamostat mesylate treatment in combination with favipiravir for patients critically ill with Covid-19: a case series. Crit Care 24:392. https://doi.org/ 10.1186/s13054-020-03078-Z

Dong XX, Fu J, Yin XB, Cao SL, Li XC, Lin LF, Huyiligeqi NJ (2016) Emodin: a review of its pharmacology, toxicity and pharmacokinetics. Phytother Res 30:1207-1218

Du L, Yang Y, Zhou Y, Lu L, Li F, Jiang S (2017) MERS-CoV spike protein: a key target for antivirals. Expert Opin Ther Targets 21(2):131-143. https://doi.org/10.1080/14728222.2017.1271415

Dunn LA, Fury MG, Sherman EJ, Ho AA, Katabi N, Haque SS et al (2018) Phase I study of induction chemotherapy with afatinib, ribavirin, and weekly carboplatin and paclitaxel for stage IVA/ IVB human papillomavirus-associated oropharyngeal squamous cell cancer. Head Neck 40(2):233-241

Ekins S, Mottin M et al (2020) Deja vu: stimulating open drug discovery for SARSCoV- 2. Drug Discov Today. https://doi.org/10. 1016/j.drudis.2020.03.019 (In Press-Corrected Proof)

Fehr AR, Perlman S (2015) Coronaviruses: an overview of their replication and pathogenesis. Methods Mol Biol 1282:1-23

Fell JB, Fischer JP, Baer BR, Blake JF, Bouhana K, Briere DM et al (2020) Identification of the clinical development candidate MRTX849, a covalent KRASG12C inhibitor for the treatment of cancer. J Med Chem 63:6679-6693. https://doi.org/10.1021/ acs.jmedchem.9b02052

Garuti L, Roberti M, Bottegoni G (2011) Irreversible protein kinase inhibitors. Curr Med Chem 18:2981-2994. https://doi.org/10. 2174/092986711796391705 
Ge Y, Tian T et al (2020) A data-driven drug repositioning framework discovered a potential therapeutic agent targeting COVID-19. bioRxiv. https://doi.org/10.1101/2020.03.11. 986836 (Preprint)

Graci JD, Cameron CE (2006) Mechanisms of action of ribavirin against distinct viruses. Rev Med Virol 16(1):37-48

Hardie WD, Davidson C, Ikegami M, Leikauf GD, Le Cras TD, Prestridge A et al (2008) EGF receptor tyrosine kinase inhibitors diminish transforming growth factor-alpha-induced pulmonary fibrosis. Am J Phys Lung Cell Mol Phys 294(6):L1217-L1225

Herod MR, Adeyemi OO, Ward J, Bentley K, Harris M, Stonehouse NJ et al (2019) The broadspectrum antiviral drug arbidol inhibits foot-and-mouth disease virus genome replication. J Gen Virol 100(9):1293-1302

Heurich A, HofmannWinkler H, Gierer S, Liepold T, Jahn O, Pöhlmann S (2014) TMPRSS2 and ADAM17 cleave ACE2 differentially and only proteolysis by TMPRSS 2 augments entry driven by the severe acute respiratory syndrome coronavirus spike protein. $\mathbf{J}$ Virol 88:1293-1307. https://doi.org/10.1128/JVI.02202-13

Ho TY, Wu SL, Chen JC, Li CC, Hsiang CY (2007) Emodin blocks the SARS coronavirus spike protein and angiotensin-converting enzyme 2 interaction. Antiviral Res 74:92-101

Hoffmann M, Hofmann-Winkler H, Pöhlmann S (2018) Priming time: how cellular proteases arm coronavirus spike proteins. Activation of viruses by host proteases. Springer International Publishing, Cham, pp 71-98. https://doi.org/10.1007/978-3-319-75474-1_4

Hoffmann M, Kleine-Weber H, Schroeder S, Krüger N, Herrler T, Erichsen $\mathrm{S}$ et al (2020a) SARS-CoV-2 cell entry depends on ACE2 and TMPRSS 2 and is blocked by a clinically proven protease inhibitor. Cell 181:271-278. https://doi.org/10.1016/j.cell. 2020.02.052

Hoffmann M, Kleine-Weber H, Pöhlmann S (2020b) A multibasic cleavage site in the spike protein of SARS-CoV-2 is essential for infection of human lung cells. Mol Cell 78:779-784.e5. https:// doi.org/10.1016/j.molcel.2020.04.022

Hoffmann M, Schroeder S, Kleine-Weber H et al (2020c) Nafamostat mesylate blocks activation of SARS-CoV-2: new treatment option for COVID-19. Antimicrob Agents Chemother 64:e00754-e1720

Hosseiny M, Kooraki S, Gholamrezanezhad A, Reddy S, Myers L (2020) Radiology perspective of Coronavirus Disease 2019 (COVID 19): lessons from severe acute respiratory syndrome and Middle East respiratory syndrome. Am J Roentgenol 214:10781082. https://doi.org/10.2214/AJR.20.22969

Huang Y, Yang C, Xu X, Xu W (2020) Structural and functional properties of SARS-CoV-2 spike protein: potential antivirus drug development for COVID-19. Acta Pharmacol Sin 41:1-9. https:// doi.org/10.1038/s41401-020-0485-4

Huentelman MJ, Zubcevic J, Hernandez Prada JA et al (2004) Structure-based discovery of a novel angiotensin-converting enzyme 2 inhibitor. Hypertension 44:903e906

Hulswit RJ, de Haan CA, Bosch BJ (2016) Coronavirus spike protein and tropism changes. Adv Virus Res 96:29-57

Hung IF, Lung KC, Tso EY, Liu R, Chung TW, Chu MY, Ng YY, Lo J, Chan J, Tam AR, Shum HP, Chan V, Wu AK, Sin KM, Leung WS, Law WL, Lung DC, Sin S, Yeung P, Yip CC, Zhang RR, Fung AY, Yan EY, Leung KH, Ip JD, Chu AW, Chan WM, Ng AC, Lee R, Fung K, Yeung A, Wu TC, Chan JW, Yan WW, Chan WM, Chan JF, Lie AK, Tsang OT, Cheng VC, Que TL, Lau CS, Chan KH, To KK, Yuen KY (2020) Triple combination of interferon beta- $1 \mathrm{~b}$, lopinavir-ritonavir, and ribavirin in the treatment of patients admitted to hospital with COVID-19: an openlabel, randomised, phase 2 trial. Lancet 395(10238):1695-1704. https://doi.org/10.1016/S0140-6736(20)31042-4

Jaimes JA, Whittaker GR (2018) Feline coronavirus: Insights into viral pathogenesis based on the spike protein structure and function.
Virology 517:108-121. https://doi.org/10.1016/j.virol.2017.12. 027

Kadam RU, Wilson IA (2017) Structural basis of influenza virus fusion inhibition by the antiviral drug Arbidol. Proc Natl Acad Sci U S A 114(2):206-214. https://doi.org/10.1073/pnas.1617020114

Kaitin KI (2010a) Deconstructing the drug development process: the new face of innovation. Clin Pharmacol Ther 87:356-361. https://doi.org/10.1038/clpt.2009.293

Kaitin KI (2010b) Deconstructing the drug development process: the new face of innovation. Clin Pharmacol Ther 87:356-361

Kato T, Nishio K (2006) Clinical aspects of epidermal growth factor receptor inhibitors: benefit and risk. Respirology 11:693-698

Kern DM, Sorum B, Hoel CM, Sridharan S, Remis JP, Toso DB et al (2020) Cryo-EM structure of the SARS-CoV-2 3a ion channel in lipid nanodiscs. bioRxiv. https://doi.org/10.1101/2020.06.17. 156554

Khalili JS, Zhu H, Mak NSA, Yan Y, Zhu Y (2020) Novel coronavirus treatment with ribavirin: groundwork for an evaluation concerning COVID-19. J Med Virol. https://doi.org/10.1002/jmv.25798

Kijima M, Yoshida M, Sugita K, Horinouchi S, Beppu T (1993) Trapoxin, an antitumor cyclic tetrapeptide, is an irreversible inhibitor of mammalian histone deacetylase. J Biol Chem 268:22429-22435

Kim HS, Lee KE, Oh JH, Jung CS, Choi D, Kim Y, Noh H (2016) Cardiac arrest caused by nafamostat mesilate. Kidney Res Clin Practice 35(3):187-189. https://doi.org/10.1016/j.krcp.2015.10.003

Kimura F, Takahashi A, Kitazawa J et al (2020) (2020) Successful conservative treatment for massive uterine bleeding with nonseptic disseminated intravascular coagulation after termination of early pregnancy in a woman with huge adenomyosis: case report. BMC Womens Health 20:56

Kirchdoerfer RN, Cottrell CA, Wang N, Pallesen J, Yassine HM, Turner HL, Corbett KS, Graham BS, McLellan JS, Ward AB (2016) Pre-fusion structure of a human coronavirus spike protein. Nature 531:118-121

Kirchdoerfer RN et al (2020) Stabilized coronavirus spikes are resistant to conformational changes induced by receptor recognition or proteolysis. Sci Rep 8:15701

Knowles SR, Phillips EJ, Dresser L, Matukas L (2003) Common adverse events associ- ated with the use of ribavirin for severe acute respiratory syndrome in Canada. Clin Infect Dis 37:11391142. https://doi.org/10.1086/378304

Kollias A, Kyriakoulis KG, Dimakakos E, Poulakou G, Stergiou GS, Syrigos K (2020) Thromboembolic risk and anticoagulant therapy in COVID-19 patients: emerging evidence and call for action. Br J Haematol. https://doi.org/10.1111/bjh.16727

Krempl C, Schultze B, Laude H, Herrler G (1997) Point mutations in the $\mathrm{S}$ protein connect the sialic acid binding activity with the enteropathogenicity of transmissible gastroenteritis coronavirus. J Virol 71(4):3285-3287. https://doi.org/10.1128/JVI.71.4.32853287.1997

Künkel F, Herrler G (1993) Structural and functional analysis of the surface protein of human coronavirus OC43. Virology 195(1):195-202. https://doi.org/10.1006/viro.1993.1360

Lan J et al (2020) Structure of the SARS-CoV-2 spike receptor-binding domain bound to the ACE2 receptor. Nature 30:1-6

Lee N, Allen CK, Hui DS, Ng EK, Wu A, Chiu RW et al (2004) Effects of early corticos- teroid treatment on plasma SARS-associated coronavirus RNA concentrations in adult patients. J Clin Virol 31:304-309. https://doi.org/10.1016/j.jcv.2004.07.006

Li F (2015) Receptor recognition mechanisms of coronaviruses: a decade of structural studies. J Virol 89(4):1954-1964

Li F (2016) Structure, function and evolution of coronavirus spike proteins. Annu Rev Virol 3:237-261

Li F (2020) Evidence for a common evolutionary origin of coronavirus spike protein receptor-binding subunits. J Virol 86:2856-2858 
Li F, Li W, Farzan M, Harrison SC (2005) Structure of SARS coronavirus spike receptor-binding domain complexed with receptor. Science 309(5742):1864-1868

Li Q, Wang Z, Zheng Q, Liu S (2020) Potential clinical drugs as covalent inhibitors of the priming proteases of the spike protein of SARS-CoV-2. Comput Struct Biotechnol J 18:2200-2208. https://doi.org/10.1016/j.csbj.2020.08.016

Li C, Li W, Lucio de Esesarte E, Guo H, van den Elzen P, Aarts E, van den Born E, Rottier PJM, Bosch B-J (2017) Cell attachment domains of the porcine epidemic diarrhea virus spike protein are key targets of neutralizing antibodies. J Virol 91(12):e00273-e1217. https://doi.org/10.1128/JVI.00273-17

Lu G, Wang Q, Gao GF (2015) Bat-to-human: spike features determining "host jump" of coronaviruses SARS-CoV, MERS-CoV, and beyond. Trends Microbiol 23(8):468-478

Madu IG, Roth SL, Belouzard S, Whittaker GR (2009) Characterization of a highly conserved domain within the severe acute respiratory syndrome coronavirus spike protein $\mathrm{S} 2$ domain with characteristics of a viral fusion peptide. J Virol 83(15):7411-7421. https://doi.org/10.1128/JVI.00079-09

Mah R, Thomas JR, Shafer CM (2014) Drug discovery considerations in the development of covalent inhibitors. Bioorg Med Chem Lett 24:33-39. https://doi.org/10.1016/j.bmcl.2013.10.003

Matsuyama S, Nao N, Shirato K, Kawase M, Saito S, Takayama I, Nagata N, Sekizuka T, Katoh H, Kato F, Sakata M, Tahara M, Kutsuna S, Ohmagari N, Kuroda M, Suzuki T, Kageyama T, Takeda M (2020) Enhanced isolation of SARS-CoV-2 by TMPRSS2-expressing cells. Proc Natl Acad Sci USA 117:70017003. https://doi.org/10.1073/pnas.2002589117Medline

Maxmen A (2020) More than 80 clinical trials launch to test coronavirus treatments. Nature 578:347-348. https://doi.org/10.1038/ d41586-020-00444-3

Midgley I et al (1994) Metabolic fate of 14C-camostat mesylate in man, rat and dog after intravenous administration. Xenobiotica 24:79-92

Millet JK, Whittaker GR (2014) Host cell entry of Middle East respiratory syndrome coronavirus after two-step, furin-mediated activation of the spike protein. Proc Natl Acad Sci USA 111(42):15214-15219. https://doi.org/10.1073/pnas.1407087111

Millet JK, Whittaker GR (2015) Host cell proteases: critical determinants of coronavirus tropism and pathogenesis. Virus Res 202:120-134

Millet JK, Whittaker GR (2018) Physiological and molecular triggers for SARS-CoV membrane fusion and entry into host cells. Virology $517: 3-8$

Nazario de Moraes L, Tommasini Grotto RM, Targino Valente G, de Carvalho SH, Magro AJ, Fogaça L et al (2019) A novel molecular mechanism to explain mutations of the HCV protease associated with resistance against covalently bound inhibitors. Virus Res 274:197778. https://doi.org/10.1016/j.virusres.2019.197778

Ohki S, Nishiyama H, Ozeki K, Ito H, Hirata F (1980) Studies on absorption, distribution, metabolism and excretion of [14C] FOY-305. Gendai-Iryo 12:71-82

Omrani AS, Saad MM, Baig K, Bahloul A, Abdul-Matin M, Alaidaroos AY et al (2014) Ribavirin and interferon alfa-2a for severe Middle East respiratory syn- drome coronavirus infection: a retrospective cohort study. Lancet Infect Dis 14:1090-1095. https:// doi.org/10.1016/S1473-3099(14)70920-X

Ou J, Zhou Z, Dai R, Zhang J, Lan W, Zhao S et al (2020) Emergence of RBD mutations in circulating SARS-CoV-2 strains enhancing the structural stability and human ACE2 receptor affinity of the spike protein. Microbiology. https://doi.org/10.1101/2020. 03.15 .991844

Pallesen J et al (2017) Immunogenicity and structures of a rationally designed prefusion MERS-CoV spike antigen. Proc Natl Acad Sci USA 114:E7348-E7357
Pecheur EI, Borisevich V, Halfmann P, Morrey JD, Smee DF, Prichard $M$ et al (2016) The synthetic antiviral drug arbidol inhibits globally prevalent pathogenic viruses. J Virol 90(6):3086-3092. https://doi.org/10.1128/JVI.02077-15

Ramsey ML, Nuttall J, Hart PA (2019) A phase 1/2 trial to evaluate the pharmacokinetics, safety, and efficacy of NI-03 in patients with chronic pancreatitis: study protocol for a randomized controlled trial on the assessment of camostat treatment in chronic pancreatitis (TACTIC). Trials 20(1):501. https://doi.org/10.1186/ s13063-019-3606-y

Sanders JM, Monogue ML, Jodlowski TZ, Cutrell JB (2020) Pharmacologic treatments for coronavirus disease 2019 (COVID-19): a review. J Am Med Assoc. https://doi.org/10.1001/jama.2020. 6019

Scagliotti GV, Selvaggi G, Novello S, Hirsch FR (2004) The biology of epidermal growth factor receptor in lung cancer. Clin Cancer Res 10:4227s-4232S

Schwarz S, Wang K, Yu WJ, Sun B, Schwarz W (2011) Emodin inhibits current through SARS-associated coronavirus 3a protein. Antivir Res 90:64-69

Shang J, Ye G, Shi K, Wan Y, Luo C, Aihara H, et al. (2020) Structural basis of receptor recognition by SARS-CoV-2. Nature. https:// www.nature.com/articles/s41586-020-2179-y

Sim J, Saunders B, Kingstone T, Waterfield J (2018) Saturation in qualitative research: exploring its conceptualization and operationalization. Qual Quant 52:1893-1907. https://doi.org/10.1007/ s11135-017-0574-8

Singh J, Petter RC, Baillie TA, Whitty A (2011) The resurgence of covalent drugs. Nat Rev Drug Discov 10:307-317. https://doi. org/10.1038/nrd3410

Sonawane A, Singh S, Sk F, Kar P, Sadhukhan S (2020a) Plant-derived natural polyphenols as potential antiviral drugs against SARSCoV-2 via RNA-dependent RNA polymerase (RdRp) inhibition: an in-silico analysis. J Biomol Struct Dyn 1-16. https://doi.org/ 10.1080/07391102.2020.1796810

Sonawane K, Barale SS, Dhanavade MJ, Waghmare SR, Nadaf NH, Kamble SA et al (2020b) Homology modeling and docking studies of TMPRSS2 with experimentally known inhibitors camostat mesylate, nafamostat and bromhexine hydrochloride to control SARS-coronavirus-2. ChemRxiv. https://doi.org/10.26434/chemr xiv.12162360.v1

Tortorici MA, Veesler D (2019) Structural insights into coronavirus entry. Adv Virus Res 105:93-116. https://doi.org/10.1016/bs. aivir.2019.08.002

Towler P, Staker B, Prasad SG et al (2004) ACE2 X-ray structures reveal a large hinge-bending motion important for inhibitor binding and catalysis. J Biol Chem 279(17):17996-18007

Tsou H-R, Overbeek-Klumpers EG, Hallett WA, Reich MF, Floyd MB, Johnson BD et al (2005) Optimization of 6,7-disubstituted4-(arylamino) quinoline-3- carbonitriles as orally active, irreversible inhibitors of human epidermal growth factor receptor-2 kinase activity. J Med Chem 48:1107-1131. https://doi.org/10. $1021 / \mathrm{jm} 040159 \mathrm{c}$

Venkataraman T, Frieman MB (2017) The role of epidermal growth factor receptor (EGFR) signaling in SARS coronavirus-induced pulmonary fibrosis. Antiviral Res 143:142-150

Walls AC, Tortorici MA, Bosch BJ, Frenz B, Rottier PJM, DiMaio F, Rey FA (2016) Veesler, Cryo-electron microscopy structure of a coronavirus spike glycoprotein trimer. Nature 531:114-117

Walls AC et al (2017) Tectonic conformational changes of a coronavirus spike glycoprotein promote membrane fusion. Proc Natl Acad Sci USA 114:11157-11162

Walls AC et al (2019) Unexpected receptor functional mimicry elucidates activation of coronavirus fusion. Cell 176:1026-1039

Walls AC, Young-Jun Park M, Tortorici A, Wall A, McGuire AT, Veesler D (2020) Structure, function, and antigenicity of the 
SARS-CoV-2 spike glycoprotein. Cell 181(2):281-292. https:// doi.org/10.1016/j.cell.2020.02.058

Wan Y, Shang J, Graham R, Baric RS, Li F (2020) Receptor recognition by the novel coronavirus from wuhan: an analysis based on decade-long structural studies of SARS coronavirus. J Virol 94(7):e00127-e220. https://doi.org/10.1128/JVI.00127-20

Wang Y, Ding Y, Yang C, Li R, Du Q, Hao Y et al (2017) Inhibition of the infectivity and inflammatory response of influenza virus by Arbidol hydrochloride in vitro and in vivo (mice and ferret). Biomed Pharmacother 91:393-401

Wang Q, Zhang Y, Wu L, Niu S, Song C, Zhang Z, Lu G, Qiao C, Hu Y, Yuen KY, Wang Q, Zhou H, Yan J, Qi J (2020a) Structural and functional basis of SARS-CoV-2 entry by using human ACE2. Cell 181:894

Wang X, Cao R, Zhang H, Liu J, Xu M, Hu H et al (2020c) The antiinfluenza virus drug, arbidol is an efficient inhibitor of SARSCoV-2 in vitro. Cell Discov 6:28

Wang Y, Zhang D, Du G, Du R, Zhao J, Jin Y, Fu S, Gao L, Cheng Z, Lu Q, Hu Y, Luo G, Wang K, Lu Y, Li H, Wang S, Ruan S, Yang C, Mei C, Wang Yi, Ding D, Wu F, Tang X, Ye X, Ye Y, Liu B, Yang J, Yin W, Wang A, Fan G, Zhou F, Liu Z, Gu X, Xu J, Shang L, Zhang Y, Cao L, Guo T, Wan Y, Qin H, Jiang Y, Jaki T, Hayden FG, Horby PW, Cao B, Wang C (2020b) Remdesivir in adults with severe COVID-19: a randomised, double-blind, placebo-controlled, multicentre trial. Lancet 395:1569-1578. https://doi.org/10.1016/S0140-6736(20)31022-9

Watanabe Y, Allen JD, Wrapp D, McLellan JS, Crispin M (2020a) Site-specific glycan analysis of the SARS-CoV-2 spike. Science 369:330-333

Watanabe Y, Berndsen ZT, Raghwani J, Seabright GE, Allen JD, Pybus OG, McLellan JS, Wilson IA, Bowden TA, Ward AB, Crispin M (2020b) Vulnerabilities in coronavirus glycan shields despite extensive glycosylation. Nat Commun 11(1):2688

Wind S, Giessmann T, Jungnik A, Brand T, Marzin K, Bertulis J et al (2014) Pharmacokinetic drug interactions of afatinib with rifampicin and ritonavir. Clin Drug Investig 34(3):173-182

Wrapp D, Wang N, Corbett KS, Goldsmith JA, Hsieh CL, Abiona O, Graham BS, McLellan JS (2020) Cryo-EM structure of the 2019-nCoV spike in the prefusion conformation. Science 367(6483):1260-1263. https://doi.org/10.1126/science.abb2507

Wu C, Liu Y, Yang Y, Zhang P, Zhong W, Wang Y, Wang Q, Xu Y, Li M, Li X, Zheng M (2020a) Analysis of therapeutic targets for SARS-CoV-2 and discovery of potential drugs by computational methods. Acta Pharm Sin B 10(5):766-788
Wu R, Wang L, Kuo H-CD, Shannar A, Peter R, Chou PJ, Li S, Hudlikar R, Liu X, Liu Z, Poiani GJ, Amorosa L, Brunetti L, Kong A-N (2020b) An update on current therapeutic drugs treating COVID-19. Curr Pharmacol. https://doi.org/10.1007/ s40495-020-00216-7

Xia S, Zhu Y, Liu M, Lan Q, Xu W, Wu Y et al (2020) Fusion mechanism of 2019-nCoV and fusion inhibitors targeting HR1 domain in spike protein. Cell Mol Immunol 17:765-767

Yamamoto M, Kiso M, Sakai-Tagawa Y et al (2020) The anticoagulant nafamostat potently inhibits SARS-CoV-2 S proteinmediated fusion in a cell fusion assay system and viral infection in vitro in a cell-type-dependent manner. Viruses 12:E629

Yamamoto M, Matsuyama S, Li X, Takeda M, Kawaguchi Y, Inoue JI, Matsuda Z (2016) Identification of nafamostat as a potent inhibitor of Middle East respiratory syndrome coronavirus S proteinmediated membrane fusion using the split-protein-based cell-cell fusion assay. Antimicrob Agents Chemother 60(11):6532-6539. https://doi.org/10.1128/AAC.01043-16

Yan R, Zhang Y, Li Y, Xia L, Guo Y, Zhou Q (2020) Structural basis for the recognition of the SARS-CoV-2 by full-length human ACE2. Science 367(6485):1444-1448

Yousefi B, Valizadeh S, Ghaffari H, Vahedi A, Karbalaei M, Eslami M (2020) A global treatment for coronaviruses including COVID19. J Cell Physiol. https://doi.org/10.1002/jcp.29785

Zhang D-H, Wu K-L et al (2020) In silico screening of Chinese herbal medicines with the potential to directly inhibit 2019 novel coronavirus. J Integr Med 18(2):152-158. https://doi.org/10.1016/j. joim.2020.02.005

Zhong H, Wang Y, Zhang Z-L, Liu Y-X, Le K-J, Cui M, Yu Y-T, Gu Z-C, Gao Y, Lin H-W (2020) Efficacy and safety of current therapeutic options for COVID-19-lessons to be learnt from SARS and MERS epidemic: a systematic review and meta-analysis. Pharmacol Res. https://doi.org/10.1016/j.phrs.2020.104872

Zhou H, Chen Y, Zhang S, Niu P, Qin K, Jia W, Huang B, Zhang S, Lan J, Zhang L, Tan W, Wang X (2019) Structural definition of a neutralization epitope on the N-terminal domain of MERS-CoV spike glycoprotein. Nat Commun 10(1):3068. https://doi.org/10. 1038/s41467-019-10897-4

Zhou YD, Hou Y, Shen JY, Huang Y, Martin W, Cheng FX (2020) Network-based drug repurposing for novel coronavirus 2019nCoV/SARS-CoV-2. Cell Discov 6:1-18

Zhu Z, Lu Z, Xu T, Chen C, Yang G, Zha T, Lu J, Xue Y (2020) Arbidol monotherapy is superior to lopinavir/ritonavir in treating COVID-19. J Infect. https://doi.org/10.1016/j.jinf.2020.03.060 